\title{
Ammonia Concentration in Saltstone Headspace - Summary Report
}

J.R. Zamecnik

A.D. Cozzi

September 2008

Engineering and Chemical Process Technology Savannah River National Laboratory Aiken, SC 29808

This document was prepared in conjunction with work accomplished under Contract No. DE-AC09-08SR22470 with the U.S. Department of Energy.

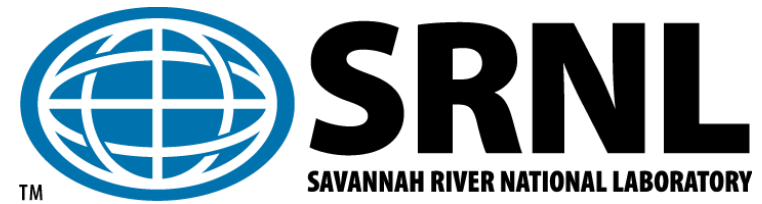




\section{DISCLAIMER}

This work was prepared under an agreement with and funded by the U.S. Government. Neither the U.S. Government or its employees, nor any of its contractors, subcontractors or their employees, makes any express or implied: 1 . warranty or assumes any legal liability for the accuracy, completeness, or for the use or results of such use of any information, product, or process disclosed; or 2. representation that such use or results of such use would not infringe privately owned rights; or 3. endorsement or recommendation of any specifically identified commercial product, process, or service. Any views and opinions of authors expressed in this work do not necessarily state or reflect those of the United States Government, or its contractors, or subcontractors.

This document was prepared in conjunction with work accomplished under Contract No. DE-AC09-08SR22470 with the U.S. Department of Energy. 
SRNS-STI-2008-00119

Revision 0

Keywords: flammables, saltstone, flowsheet

Retention: permanent

\section{Ammonia Concentration in Saltstone Headspace - Summary Report}

J.R. Zamecnik

A.D. Cozzi

September 2008

Engineering and Chemical Process Technology Savannah River National Laboratory Aiken, SC 29808

This document was prepared in conjunction with work accomplished under Contract No. DE-AC09-08SR22470 with the U.S. Department of Energy.

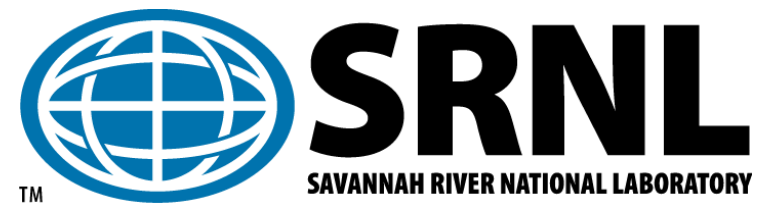




\section{REVIEWS AND APPROVALS}

AUTHORS:

J.R. Zamecnik, Engineering Process Development

Date

A.D. Cozzi, Engineering Process Development

Date

\section{TECHNICAL REVIEWER:}

\begin{tabular}{lc}
\hline D.C. Koopman, Process Engineering Technology & Date
\end{tabular}

\section{APPROVERS:}

A.B. Barnes, Manager, Engineering Process Development

Date

J.C. Griffin, Manager,

Date

Environmental \& Chemical Process Technology Research Programs

J.E. Occhipinti, Manager, Waste Solidification Engineering

Date 


\section{EXECUTIVE SUMMARY}

The Saltstone Facility Documented Safety Analysis (DSA) is under revision to accommodate changes in the Composite Lower Flammability Limit (CLFL) from the introduction of Isopar into Tank 50. Saltstone samples were prepared with an "MCU" type salt solution spiked with ammonia. The ammonia released from the saltstone was captured and analyzed. The ammonia concentration found in the headspace of samples maintained at $95{ }^{\circ} \mathrm{C}$ and $1 \mathrm{~atm}$ was, to $95 \%$ confidence, less than or equal to $3.9 \mathrm{mg} / \mathrm{L}$. 


\section{TABLE OF CONTENTS}

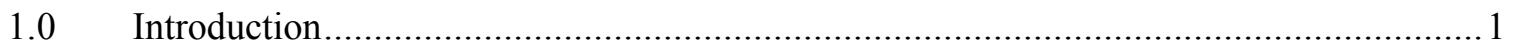

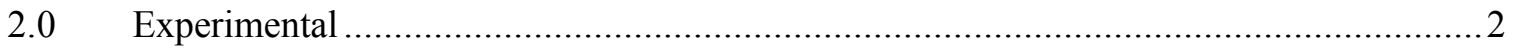

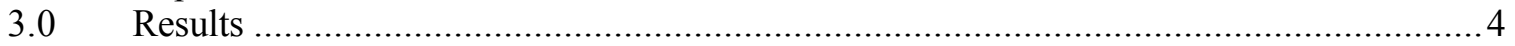

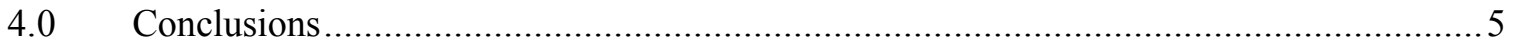

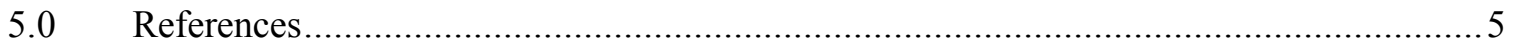




\subsection{Introduction}

Tank 50 is fed by several influent streams. The salt solution from Tank 50 is pumped to the salt feed tank (SFT) in the Saltstone Production Facility (SPF). The premix materials cement, slag and fly ash are blended together prior to transfer to the grout mixer. The premix is fed to the grout mixer in the SPF and the salt solution is incorporated into the premix in the grout mixer, yielding saltstone slurry. The saltstone slurry drops into a hopper and then is pumped to the vault.

The Saltstone Facility Documented Safety Analysis (DSA) is under revision to accommodate changes in the Composite Lower Flammability Limit (CLFL) from the introduction of Isopar ${ }^{\circledR} \mathrm{L}$ into Tank 50.

Waste Solidification-Engineering requested that the Savannah River National Laboratory (SRNL) perform testing to characterize the release of ammonia in curing saltstone at $95{ }^{\circ} \mathrm{C}$. ${ }^{1}$ The test temperature represents the maximum allowable temperature in the Saltstone Disposal Facility (SDF). ${ }^{2}$ Ammonia may be present in the salt solution and premix materials, or may be produced by chemical reactions when the premix and salt solution are combined.

A final report (SRNS-STI-2008-00120, Rev. 0) will be issued that will cover in more depth the information presented in this report. 


\subsection{Experimental}

Saltstone samples were prepared using an MCU-type salt solution spiked with 0, 50 and 200 $\mathrm{mg} / \mathrm{L}$ ammonia as ammonium chloride. Table 2-1 shows the composition and physical properties of the salt solution used. The premix materials were cement and blast furnace slag from Holcim, the supplier for the SPF, and fly ash from the SEFA Carbon Burn Out (CBO) process at the Wateree power station. Table $2-2$ is the premix blend used in this study. The ammonia contribution from the premix materials was determined by Eibling to be $<2,10.1$, and $<2 \mathrm{mg} / \mathrm{kg}$ for the CBO flay ash, blast furnace slag, and cement, respectively. ${ }^{3}$ The ammonia content of the slag would introduce about $0.37 \mathrm{mg}$ of ammonia to each saltstone sample tested. The admixtures Daratard 17 (set retarder) and Clear Air 100 (antifoam) were added using the dosages representing recent SPF operations. No ammonia contribution is expected from the admixtures. However, the admixtures were included in the unlikely event that they participate in the reactions that generate ammonia. Table 2-3 is a data sheet representative of the three mixes prepared in this study.

Table 2-1 Composition and Properties of Salt Simulant

\begin{tabular}{|c|c|}
\hline Species & $\begin{array}{c}\text { Concentration } \\
(\mathbf{M}, \mathbf{m o l} / \mathbf{L})\end{array}$ \\
\hline $\mathrm{Na}^{+}$ & 5.61 \\
\hline $\mathrm{OH}^{-}$ & 1.37 \\
\hline $\mathrm{NO}_{3}^{-}$ & 3.31 \\
\hline $\mathrm{NO}_{2}^{-}$ & 0.37 \\
\hline $\mathrm{CO}_{3}^{-2}$ & 0.18 \\
\hline $\mathrm{SO}_{4}^{-2}$ & 0.059 \\
\hline $\mathrm{Al}^{+3}$ & 0.054 \\
\hline $\mathrm{PO}_{4}^{-3}$ & 0.012 \\
\hline Weight Percent Solids (Water) & $31.5(68.5)$ \\
\hline Density (g/cm & 1.26 \\
\hline
\end{tabular}

Table 2-2 Premix Blend

\begin{tabular}{|c|c|}
\hline Material & Weight Percent \\
\hline cement & 10 \\
\hline blast furnace slag & 45 \\
\hline fly ash (CBO) & 45 \\
\hline
\end{tabular}


Table 2-3 Representative Data Sheet of the Mixes

\begin{tabular}{|c|c|c|c|}
\hline \multicolumn{4}{|c|}{ Saltstone Mix Data Sheet } \\
\hline \multicolumn{2}{|l|}{ MIX \# 0100} & \multicolumn{2}{|c|}{ Date: $\quad 9 / 4 / 2008$} \\
\hline Material & $\%$ & WT $\%$ & Grams \\
\hline \multirow{2}{*}{ 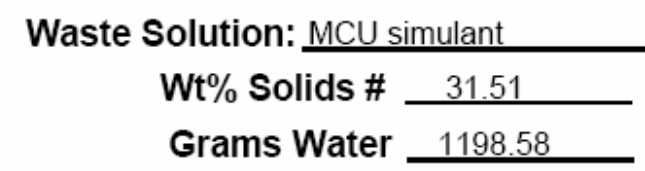 } & & \multirow[b]{2}{*}{46.62} & \multirow[b]{2}{*}{1750.00} \\
\hline & & & \\
\hline Admixture: $\quad$ Daratard 17 & & 0.08 & 1.60 \\
\hline Admixture: $\quad$ Clear Air 100 & & 0.11 & 2.20 \\
\hline \multicolumn{4}{|l|}{ Admixture: } \\
\hline Premix & & 53.28 & 2000.00 \\
\hline Cement ( $\%$ of Premix) & 10 & 5.33 & 200.00 \\
\hline Slag ( $\%$ of Premix) & 45 & 23.98 & 900.00 \\
\hline Fly Ash ( $\%$ of Premix) & 45 & 23.98 & 900.00 \\
\hline Total & 100 & 100.1 & 3753.80 \\
\hline Water to Premix Ratio & \multicolumn{2}{|c|}{0.60} & \\
\hline
\end{tabular}

The salt solution and premix were combined and mixed for three minutes with a Rushton blade mixer. The saltstone slurry was poured into glass vessels and placed into a hot block heating apparatus and heated to $95^{\circ} \mathrm{C}$. Samples of salt solution only were also tested.

Two different types of tests were performed. In one test type (called 'open'), the vessel headspace was open to the atmosphere via a $0.6-\mathrm{cm}$ diameter opening that was plugged with a porous pipette filter. The amount of ammonia in the headspace was measured by placing a sulfuric acid impregnated silica gel tube (SKC Inc. \#226-10-06) into the vent in place of the filter and then purging with 2-3 headspace volumes of air. The filter was then replaced into the vent until the next measurement.

In the second type of test (called 'total') the silica gel tube was placed into the vent and remained there until sampled. Sampling consisted of removing the tube for analysis, placing a new tube into the vent and purging to sample the headspace as done for the open vessels. A new tube was then placed into the vent and remained there until the next sampling.

The silica gel was transferred from the sampling tube to a vial containing $10 \mathrm{~mL}$ of $0.1 \mathrm{M}$ sulfuric acid. The vials were submitted to $\mathrm{F} / \mathrm{H}$ Lab for analysis of ammonia concentration using an ion selective electrode (ISE). ${ }^{4}$ 
The concentrations of ammonia over salt solutions and $\mathrm{pH} 12$ water at $95{ }^{\circ} \mathrm{C}$ were estimated using the OLI Systems Aqueous Electrolyte Simulation software (StreamAnalyzer, version 2.0.58). The Henry's law constant for ammonia over salt solution was calculated using the solution composition given in Table 2-1. The value of the Henry's law constant used was 1.94 $\mathrm{m} / \mathrm{atm}$, where $\mathrm{m}$ is molal ( $\mathrm{mol} / \mathrm{kg}$ water). The expected concentrations of ammonia in the vapor space over salt solution at $95{ }^{\circ} \mathrm{C}$, using a Henry's law constant of $1.94 \mathrm{~m} / \mathrm{atm}$, are shown in Table 2-4. The ammonia concentration above water at $\mathrm{pH} 12$ is also shown.

The calculated Henry's law constant for the MCU salt solution at $5.6 \mathrm{M} \mathrm{Na}^{+}$and $1.37 \mathrm{M} \mathrm{OH}^{-}$is 1.94, versus the value from the correlation developed by PNNL for a specific tank waste simulant containing $6.2 \mathrm{M} \mathrm{Na}^{+}$and $1.7 \mathrm{M} \mathrm{OH}^{-}$, which was $2.47 \mathrm{~m} / \mathrm{atm} .^{5}$ For comparison, the PNNL simulant composition was simulated in OLI to give a predicted Henry's law constant of $1.63 \mathrm{~m} / \mathrm{atm}$.

\section{Table 2-4 Calculated Equilibrium Ammonia in Headspace}

\begin{tabular}{|cccc|}
\multicolumn{1}{c}{ Solution } & $\begin{array}{c}\text { Henry's Law } \\
\text { Constant } \\
(\mathrm{m} / \mathrm{atm})\end{array}$ & $\begin{array}{c}\text { Ammonia } \\
\text { (atm) }\end{array}$ & $\begin{array}{c}\text { Ammonia } \\
(\mathrm{mg} / \mathrm{L})\end{array}$ \\
\hline $\begin{array}{c}\text { Salt Solution with } \\
50 \mathrm{mg} / \mathrm{L} \mathrm{NH} \mathrm{NH}_{3}\end{array}$ & 1.94 & 0.00175 & 0.990 \\
\hline $\begin{array}{c}\text { Salt Solution with } \\
200 \mathrm{mg} / \mathrm{L} \mathrm{NH}\end{array}$ & 1.94 & 0.00702 & 3.96 \\
\hline $\begin{array}{c}\text { Water with } 200 \mathrm{mg} / \mathrm{L} \\
\mathrm{NH}_{3} \text { at } \mathrm{pH} 12\end{array}$ & 4.52 & 0.00195 & 1.10 \\
\hline
\end{tabular}

\subsection{Results}

Saltstone made from both $50 \mathrm{mg} / \mathrm{L}$ and $200 \mathrm{mg} / \mathrm{L}$ salt solution and from salt solution only were tested for a duration of seven days. Samples from the 'total' tests were taken at 1, 2, 4, and 7 days duration. 'Open' test samples were taken at various times - some were sampled after 1, 2, or 3 days, and some were sampled more than once (e.g., 1, 3, 5, 7 days).

Based on the results from the headspace purges of the salt solution vessels, the 'total' test vessels were found to be the most representative of the equilibrium amount of ammonia expected in the headspace. In these samples, the sampling tube that was always installed in the vent became filled with a small amount of condensed water, which resulted in less total evaporation of water from the samples and also less loss of ammonia due to the water flux. The saltstone 'total' test samples, with the tubes always installed, lost an average of $1.9 \%$ of their initial weight, whereas the 'open' samples lost $6.3 \%$.

A sample of salt solution only was also tested using the 'total' method. The expected amount of ammonia in the headspace was $0.344 \mathrm{mg}$. The actual headspace average amount measured was $0.350 \mathrm{mg}$, indicating that the headspace amount of ammonia from the 'total' method gave good agreement with the predicted amount.

For triplicate tests of saltstone from $200 \mathrm{mg} / \mathrm{L} \mathrm{NH}_{3}$ in salt solution, the mean amount of ammonia detected in the headspace was $0.226 \mathrm{mg}$. Based on 12 measurements, the upper one-sided $95 \%$ 
confidence on this value is $0.338 \mathrm{mg}$ compared to the calculated equilibrium value of $0.344 \mathrm{mg}$. The concentration in the headspace at $95 \%$ confidence is then $3.9 \mathrm{mg} / \mathrm{L}$.

\subsection{Conclusions}

The headspace concentration of ammonia from saltstone made from MCU salt simulant with 200 $\mathrm{mg} / \mathrm{L}$ ammonia to $95 \%$ confidence is $3.9 \mathrm{mg} / \mathrm{L}$. Premix materials used were fly ash and cement with no detectable ammonia and slag with about $10 \mathrm{mg} / \mathrm{kg}$ ammonia.

\subsection{References}

${ }^{1}$ HLW-SSF-2008-011 Rev. 1. Determine the Amount and Timing of Releases of Ammonia from Saltstone Grout

${ }^{2}$ WSRC-SA-2003-00001, Revision 5, Saltstone Facility Documented Safety Analysis

${ }^{3}$ SRNL-L3100-2008-00025, Flammability Contributors from Saltstone Dry Feed Materials

${ }^{4}$ Procedure: L3.05-10120, Ammonia Analysis: Direct Calibration

${ }^{5}$ J.D. Norton, L.R. Pederson, Ammonia in Simulated Hanford Double-Shell Tank Wastes:

Solubility and Effects on Surface Tension, PNL-10173, September 1994. 